\title{
Climatic influences on recruitment of 3 subspecies of Artemisia tridentata
}

\author{
AARON M. MAIER, BARRY L. PERRYMAN, RICHARD A. OLSON, AND ANN L. HILD
}

Authors are Ph.D. Candidate, Department of Rangeland Ecosystem Science, Colorado State University, Fort Collins, Colo. 80524; assistant professor, School of Veterinary Medicine, University of Nevada, Reno, Nev 89557; associate professor and assistant professor, Department of Renewable Resources, University of Wyoming, Laramie, Wyo. 82071.

\begin{abstract}
Previous research suggested that big sagebrush (Artemisia tridentata Nutt.) recruitment occurs in pulses consistent with favorable climatic conditions. In 1997, 75 stem sections were collected from 9 stands of each of the 3 subspecies of big sagebrush in Wyoming along elevation and climatic gradients. Annual growth rings were used to identify the year plants were established. Large cohorts of Wyoming big sagebrush (A. tridentata ssp. wyomingensis Beetle and Young) appeared in 1982, 1981, 1964, 1961, and 1955. Basin big sagebrush (A. tridentata ssp. tridentata Beetle and Johnson) cohorts flourished in 1991, 1986, 1985, 1982, and 1977. Mountain big sagebrush (A. tridentata ssp. vaseyana [Rydb.] Beetle) cohorts prospered in 1985, 1982, 1981, 1979, and 1974. Mean monthly precipitation and temperature records were compared to years with high and low recruitment using logistic regression models at 3 geographic scales (single-stand, regional, statewide). Wyoming big sagebrush recruitment was greatest in years with above-average December and January precipitation occurring after the first growing season $\left(r^{2}=0.10,0.04, P<0.05\right)$. Basin big sagebrush recruitment was most successful in years with above-average March, May, and June precipitation during the first growing season $\left(r^{2}=0.06,0.09,0.18, P<0.05\right)$. Mountain big sagebrush recruitment was greatest in years with below-average February, April, and May precipitation after the first growing season $\left(r^{2}=0.03,0.04,0.04, P<0.05\right)$. While variable precipitation patterns appear to contribute significantly to recruitment of big sagebrush, responses among the 3 major subspecies were quite variable. More complex models need to be developed to foster our understanding of the mechanisms affecting big sagebrush establishment.
\end{abstract}

Key Words: climate, big sagebrush, seedling establishment

The 3 big sagebrush (Artemisia tridentata Nutt.) subspecies have a wide ecological amplitude (Beetle and Johnson 1982) in the western United States. They help prevent erosion, provide wildlife habitat and forage, and improve rangeland aesthetics (Vale 1974). Because of big sagebrush's ecological significance in Wyoming's rangelands, the Wyoming Department of

Research was funded by the Wyoming Abandoned Coal Mined-Lands Research Program, University of Wyoming. This support was administered by the Wyoming Departmental of Environmental Quality from funds returned to the state of Wyoming from the Office of Surface Mining, U.S. Department of the Interior.

Manuscript accepted 29 Apr. 2000.

\section{Resumen}

La investigación previa sugiere que el establecimiento de "Big sagebrush" (Artemisia tridentata Nutt.) ocurre en eventos concordantes con condiciones climáticas favorables. En 1997 se colectaron 75 secciones de tallos de 9 poblaciones de cada una de las 3 subespecies de "Big sagebrush", la colecta se realizo en Wyoming a lo largo de gradientes climáticos y de elevación. Los anillos anuales de crecimiento se utilizaron para identificar el año en el que se establecieron las plantas. Generaciones grandes de "Wyoming big sagebrush" (A. tridentata ssp. wyomingensis Beetle and Young) aparecieron en 1982, 1981, 1964, 1961 y 1955. Generaciones de "Basin big sagebrush" (A. tridentata ssp. tridentata Beetle and Johnson) florecieron en 1991, 1986, 1985, 1982 y 1977. Generaciones de "Mountain big sagebrush" (A. tridentata ssp. vaseyana [Rydb.] Beetle) prosperaron en 1985, 1982, 1981, 1979 y 1974. Los registros de medias mensuales de temperatura y precipitación se compararon entre años de establecimiento alto y bajo, para ello se utilizaron modelos de regresión logística en 3 escalas geográficas (nivel de población, regional y estatal). El establecimiento de "Wyoming big sagebrush" fue mayor en años en los que la precipitación de los meses de Diciembre y Enero después de la primer estación de crecimiento fue arriba del promedio $\left(r^{2}=0.10,0.04, P<0.05\right)$. El establecimiento de "Basin big sagebrush" fue más exitoso en los años en los que la precipitación de los meses de Marzo, Mayo y Junio de la primera estación de crecimiento fue arriba del promedio $\left(r^{2}=0.06,0.09\right.$, $0.18, P<0.05)$. El establecimiento de "Mountain big sagebrush" fue mayor en años en los que la precipitación promedio de los meses de Febrero, Abril y Mayo después de la primer estación de crecimiento fue abajo del promedio $\left(\mathbf{r}^{2}=0.03,0.04,0.04, P<0.05\right)$. Mientras que patrones variables de precipitación parecen contribuir significativamente con el establecimiento de "Big sagebrush", las respuestas entre las 3 subespecies principales fue muy variable. Se necesita desarrollar modelos más complejos para avanzar en nuestro entendimiento de los mecanismos que afectan el establecimiento de "Big sagebrush".

Environmental Quality (DEQ) has legally mandated its reestablishment on disturbed mined-lands where it previously occurred. Success at reestablishing Wyoming big sagebrush (A. tridentata ssp. wyomingensis Beetle and Young) has been sporadic in northeast Wyoming, the edge of its distribution range (Lyford 1995).

Big sagebrush distribution is closely tied to temperature and precipitation (Cawker 1980). Successful recruitment of big sagebrush is partially dependent on available moisture (Sturges 1976, Cawker 1980, Lyford 1995) and seed viability (McDonough and 
Harniss 1974). Big sagebrush seedling survival is reduced when high temperatures lower available soil moisture and increase evapotranspiration rates (Young et al. 1991). Throughout most of the growing season, temperature is not as critical as moisture for big sagebrush seedling germination and survival (Harniss and McDonough 1976). Past climate appears to influence the age structure of big sagebrush stands and in drought years seedling establishment is reduced (Cawker 1980). Examination of historical climate patterns may identify specific precipitation and temperature conditions favorable for big sagebrush recruitment and survival.

Our objective was to determine if specific combinations of monthly precipitation and mean monthly temperature were correlated with high big sagebrush recruitment. To do this, long-term monthly precipitation and mean monthly temperature variables were logistically regressed against high- and no-recruitment years on native, undisturbed sagebrush stands in Wyoming.

\section{Materials and Methods}

\section{Field Sampling and Laboratory Preparation}

In 1997, we visited 27 big sagebrush sites ( 9 sites for each of the 3 subspecies) along elevation and climatic gradients in Wyoming. The 3 major subspecies we sampled were Wyoming big sagebrush, basin big sagebrush (A. tridentata ssp. tridentata Beetle and Johnson), and mountain big sagebrush (A. tridentata ssp. vaseyana [Rydb.] Beetle). At each site, 75 stem sections were collected from sagebrush. Elevations ranged from $960 \mathrm{~m}$ in the Powder River Basin of northeast Wyoming to $2,700 \mathrm{~m}$ in the Bighorn Mountains in north central Wyoming. Average annual precipitation, measured near the stands, ranged from $20 \mathrm{~cm}$ in the Bighorn Basin to $64 \mathrm{~cm}$ north of Pinedale in western Wyoming (WRDS 1997). Stands were selected with a variety of age classes of big sagebrush, similar cover and topography, and absence of excessive grazing or other disturbances. Sites were also selected to minimize supplemental moisture or subsurface runoff due to microsite influences, which reduces variations in demography between sites (Bonham et al. 1991). All stands occupied at least 1 ha.

Stem sections for Wyoming big sagebrush were collected from 3 stands in northeast Wyoming near Rochelle; 3 stands in the South Fork of the Powder River watershed, northwest of Casper in central Wyoming; and 3 stands in southwest Wyoming near Pinedale. Stem sections for basin big sagebrush were collected from 3 stands near Pinedale; 3 stands near Worland, on the west slope of the Bighorn Mountains; and 3 stands near Farson, in southwest Wyoming. Stem sections for mountain big sagebrush were collected from 3 stands near Pinedale; 3 stands near Buffalo; on the east slope of the Bighorn Mountains; and 3 stands west of Laramie, near Elk Mountain in south central Wyoming. Each of 3 stands in a regional grouping were located within a $10 \mathrm{~km}$ radius. Stand locations were determined with a Global Positioning System, and coordinates and elevations are found in Perryman and Olson (2000).

A stratified random sampling procedure (Cochran 1977) was used to select the shrubs sampled in each stand. A 100 meter baseline transect was located within each stand, 8 random points were selected along the transect, and 100 meter perpendicular transects established from each point along the baseline. Along each perpendicular transect, 10 random points were marked, and we selected the closest big sagebrush plant. Cross-sections were obtained by sawing individual plants $4-6 \mathrm{~cm}$ below ground level (Ferguson 1964) to ensure that the pith and first annual growth ring were counted. Ferguson (1964) and Cawker (1980) demonstrated that annual growth rings in big sagebrush may be used to accurately determine the age of individual plants. If a cross section had no pith it was discarded and replaced. Cross sections were smoothed using 80-200 grit sandpaper and coated with tung oil to improve contrast between annual growth rings.

Year of establishment was determined for each cross-section by enumerating annual growth rings from the pith to the exterior surface. One or more big sagebrush plants established in the same year comprised a cohort.

Inter-annual or false rings appear in conifers when secondary xylem growth surges 2 or more times in a growing season. These rings have not been encountered in big sagebrush at northern latitudes and higher elevations (Diettert 1938, Moss 1940, Ferguson 1964). Distinct growth layers in big sagebrush stems reduces the chance of misidentifying annual rings. Around some portions of a stem growth rings might not form. Complete absence of rings are rarely encountered, however, due to the unique nature of annual growth ring formation in big sagebrush (Ferguson 1964).
Many older stems were "lobed" or "rosette" in form and lacked radial symmetry. Often decumbent and decadent older stems experienced open pith exposure and loss to decomposition. Accurate age assessment was not possible without an intact pith, so our sampling favored single-stemmed plants with intact piths over individuals that lacked radial symmetry. Therefore, some older plants may have been excluded from our study.

\section{Climate Data}

All stands were located within $10 \mathrm{~km}$ of 10 separate National Weather Service climate stations. Weather data from each station was provided by WRDS (1997). Weather conditions at stands were assumed similar to nearby climate stations. Mean monthly temperatures were calculated from mean daily temperatures for each month. Data from Tensleep $4 \mathrm{NE}$ and Kaycee climate stations were averaged to approximate weather conditions at 3 stands of mountain big sagebrush at higher elevations in the Bighorn Mountains. Missing monthly precipitation and mean monthly temperature values accounted for less than 1 percent of the scheduled data for each station. Missing monthly precipitation and mean monthly temperature data were substituted with corresponding monthly values from adjacent climate stations using the normal ratio method (Brooks et al. 1991).

\section{Statistical Analyses}

Logistic regression was used to relate cohort establishment years for each subspecies to climatic variables at 3 geographic scales (stand, regional stand combination, and statewide). Within each stand, the 5 largest cohorts within each period of record and their corresponding year of establishment were assigned a value of 1 . Five years with no evidence of recruitment were randomly selected and assigned a value 0 . The bimodal frequency of establishment was represented by the dependent, dichotomous variable $\mathrm{Y}=1,0$. Independent $(\mathrm{X})$ monthly precipitation and mean monthly temperature variables were considered for 3-year periods surrounding the establishment year (pre-establishment, establishment, and post-establishment years). Cohorts established prior to 1949 were excluded from the analysis due to the absence of climate data.

For each stand, 36 monthly precipitation and 36 mean monthly temperature variables were regressed against each of the 5 recruitment years and 5 non-recruitment years. This procedure yielded a total of 
720 predictor variables in each singlestand regression model, 1080 predictor variables in each regional regression model, and 3240 predictor variables in each statewide regression model.

Logistic regression analysis, a regression for categorical data, is often used for relating climate data to population demographics (Hosmer and Lemeshow 1989, Christensen 1997). Logistic regression analyses using maximum likelihood estimation were employed to examine the relationship between climate $(\mathrm{X})$ and cohort establishment years $(Y=1,0)$. Logistic regression overcomes standard linear regression assumptions (e.g. heteroscedasticity, non-normal error terms, nonlinearity, and predicted probabilities beyond 1.0) by providing a logit dependent variable. The equation expressing the relationship between the climate $(\mathrm{X})$ and cohort $(\mathrm{Y}=1,0)$ variables is: $\operatorname{logit}(\mathrm{Y})=\alpha$ $+\beta_{1} X_{1}+\beta_{2} X_{2}+\ldots+\beta_{k} X_{k}$.

Relationships were judged significant when $\mathrm{P}<0.05$. A significant logistic regression was not used to predict specific monthly precipitation and mean monthly temperature amounts surrounding cohort establishment, but, rather climatic differences between highly successful recruitment years and years with no recruitment.

\section{Results and Discussion}

Figure 1 depicts a logistic probability plot at the regional scale. Ordered by year at the statewide scale, the 5 largest cohorts of Wyoming big sagebrush appeared in 1982, 1981, 1964, 1961, and 1955; basin

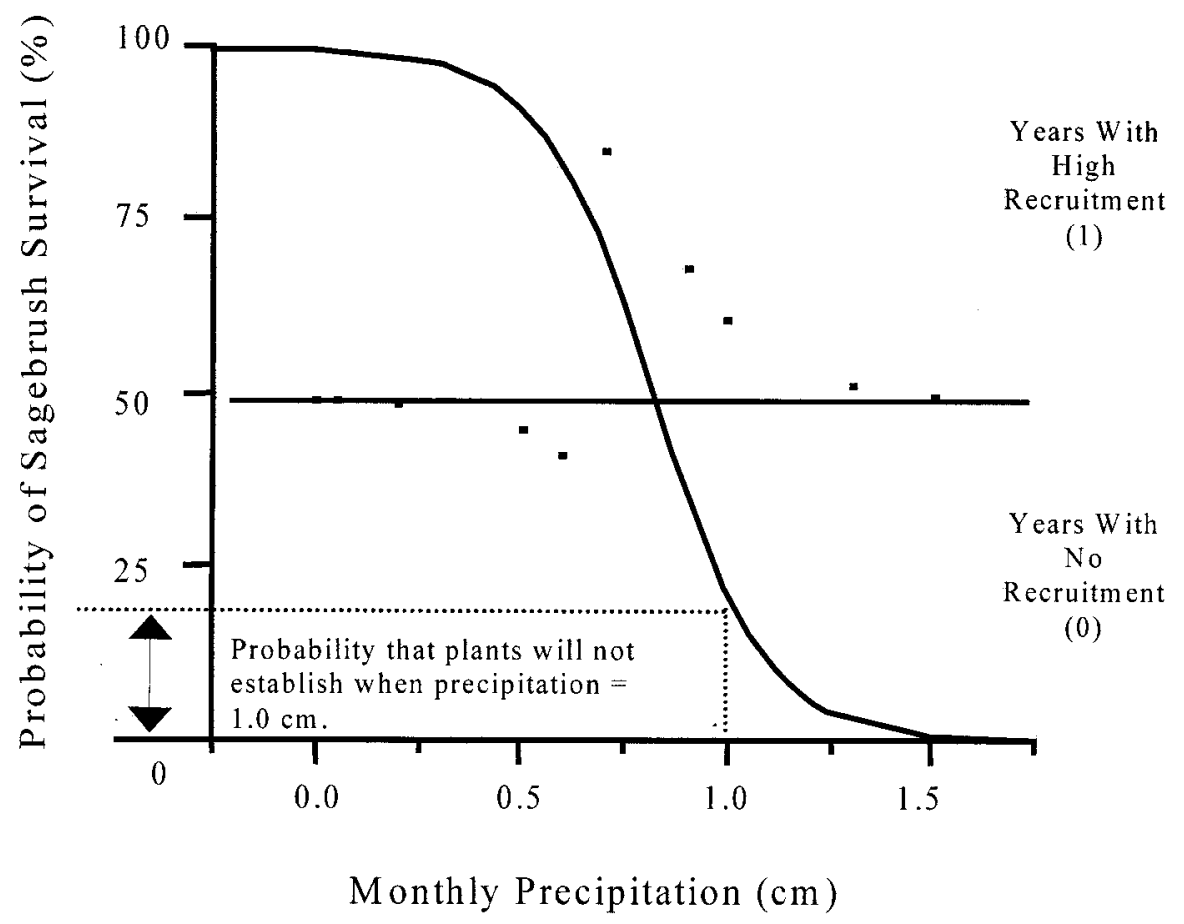

Fig. 1. Depiction of a logistic probability plot for December precipitation following initial growing season of northeast Wyoming big sagebrush. Dots represent year of establishment.

big sagebrush in 1991, 1986, 1985, 1982, and 1977; and mountain big sagebrush in 1985, 1982, 1981, 1979, and 1974.

\section{A. tridentata ssp. wyomingensis}

For Wyoming big sagebrush, 2 variables, above-average December and January precipitation immediately following seedling establishment, were positively correlated $\left(\mathrm{r}^{2}=0.10,0.04\right.$ respectively,
$\mathrm{P}<0.05$, Table 1) to seedling establishment at the statewide scale and at the northeast regional scale $\left(\mathrm{r}^{2}=0.54,0.13\right.$ respectively, $\mathrm{P}<0.05$, Table 1). The relationship between December precipitation and cohort establishment was highest in northeast Wyoming $\left(r^{2}=0.54\right)$. Coefficients of determination were relatively low because variance was spread across 360 monthly precipitation variables. We are confident that

Table 1. Significant coefficients of determination ( $\mathbf{r} 2$ ) for logistic regression models relating establishment patterns of 3 subspecies of bigsagebrush to monthly precipitation at regional and statewide scales in Wyoming.

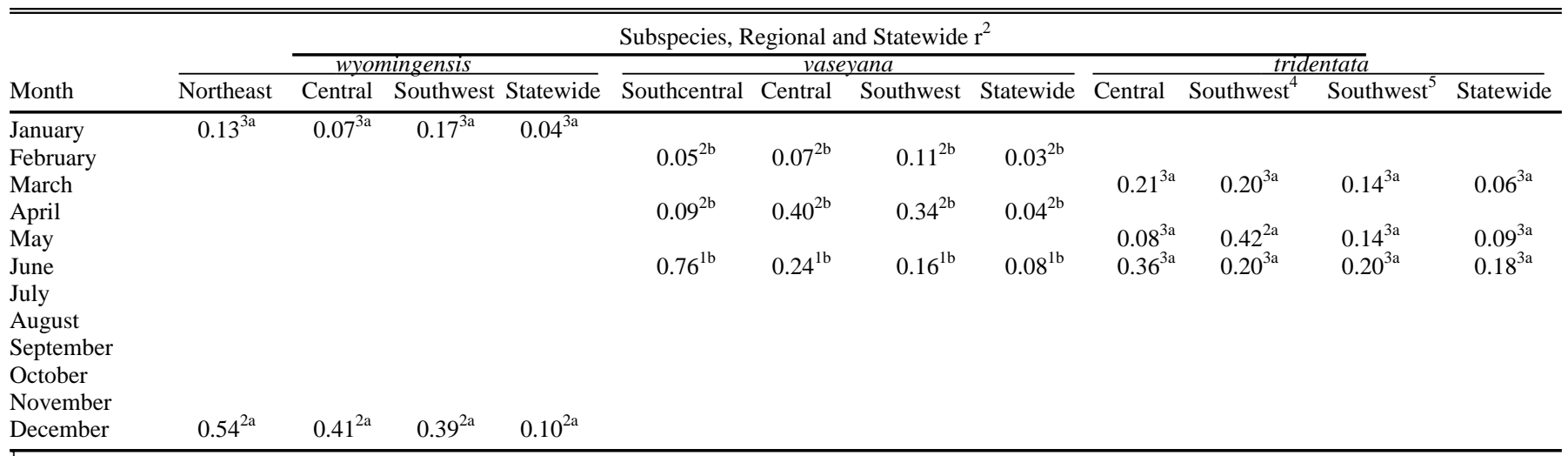

${ }^{\mathrm{T}}$ Year before Establishment

${ }_{3}^{2}$ Year of Establishment

${ }^{3}$ Year After Establishment

${ }^{4}$ West Slope of the Green River Basin

${ }^{5}$ East Slope of the Green River Basin

${ }^{\mathrm{a}}$ Indicates above-average category

${ }^{\mathrm{b}}$ Indicates below-average category 
these $r^{2}$ values indicate relationships between monthly climate and cohort establishment. Temperature variables were not significant predictors of cohort establishment $(P>0.05)$. Results indicate that Wyoming big sagebrush recruitment was high in years where the winter after the first growing season received above-average December and January precipitation, but especially high December precipitation.

In Wyoming, winter precipitation typically occurs as snow. Winters with persistent snow cover may protect juvenile Wyoming big sagebrush plants from cold temperatures and high winds, effectively enhancing survival. Conversely, little or no snow accelerates winter desiccation, possibly reducing seedling survival in years with little or no snowpack. Aboveaverage snowfall is likely to furnish more soil moisture for subsequent seedling growth. Jones (1991) hypothesized that winter precipitation and augmented deep soil moisture does not increase big sagebrush seedling survival during the year of establishment.

\section{A. tridentata ssp. tridentata}

Years of high basin big sagebrush recruitment were associated with aboveaverage June precipitation during the year of establishment $\left(\mathrm{r}^{2}=0.42, \mathrm{P}<0.05\right)$ in southwest Wyoming, and above-average March, May, and June precipitation the following year $\left(\mathrm{r}^{2}=0.06,0.09,0.18, \mathrm{P}<\right.$ $0.05)$ at the statewide scale. There were also significant relationships between temperature variables and cohort establishment. Warm December temperatures the year after establishment were positively related $\left(\mathrm{r}^{2}=0.06,0.10, \mathrm{P}<0.05\right)$ to basin big sagebrush cohort establishment. This relationship was consistent at all 3 geographic scales. It is likely that warm temperatures during December improves seedling survival. The relationship between above-average growing season moisture in years following high recruitment was greatest in southwest Wyoming $\left(r^{2}=0.14-0.42\right.$, Table 1$)$.

The precipitation variables associated with basin big sagebrush recruitment correlated significantly with periods of high moisture demand by seedlings (Eissenstat and Caldwell 1988, Bonham et al. 1991, Bai et al 1997). Basin big sagebrush seedling germination and survival in Wyoming is generally high due to high seed yields and available soil moisture (Harniss and McDonough 1976). Years with unusually high growing season moisture thus provide optimum conditions for high levels of recruitment.

\section{A. tridentata ssp. vaseyana}

Years of high mountain big sagebrush recruitment were characterized by belowaverage February, April, and June precipitation the year of establishment $\left(r^{2}=0.03\right.$, $0.04,0.04)$ across all 3 geographic scales $(\mathrm{P}<0.05$, Table 1). These coincided with the establishment of large cohorts in years of below-average spring precipitation. Young et al. (1991) and McDonough and Harniss (1974) indicated that mountain big sagebrush seedling germination is reduced with cooler temperatures. Spring moisture is coincident with cooler temperatures at high elevations, creating conditions that appear to reduce sagebrush recruitment. Since mountain big sagebrush seedling germination is generally adequate every year at high elevations (McDonough and Harniss 1974), years with unusually low spring and early summer precipitation may correspond with higher temperatures that enhance seedling survival. Our analysis indicated that temperature variables were poor predictors of recruitment, so there may be an inverse relationship between low precipitation and higher temperatures. Data from Burke et al. (1989) indicate that snow cover and its effect on soil moisture and temperature affect the distribution of mountain big sagebrush. This may be the case, but there may be climatic mechanisms operating at finer scales than evaluated by our model.

\section{Conclusions}

High levels of Wyoming big sagebrush recruitment were positively correlated with above-average winter precipitation following the first growing season; basin big sagebrush recruitment was positively correlated with growing season moisture the year of establishment; and mountain big sagebrush recruitment was positively correlated with low spring precipitation during the first growing season. These relationships were consistent across all 3 geographic levels, but strongest at the regional scale (Table 1 ). These findings support earlier evidence of climatic control of big sagebrush seedling survival (Sturges 1976, West 1978, Cawker 1980).

Since recruitment of big sagebrush cohorts occurs in years with favorable precipitation (Went 1955, May 1975, West et al. 1979, Cawker 1980), artificially creating similar conditions on disturbed minedlands might enhance recruitment. A few studies have examined the relationship of mulching and snow fences to enhance seedling establishment on reclaimed mined-lands in northeast Wyoming (Schuman et al. 1998), but no one has investigated the impacts of snow cover on seedling survival. We speculate that additional winter snow cover may be the key to reestablishment of Wyoming big sagebrush in areas of northeast Wyoming where it occurs on the edge of its distribution range.

In western Wyoming, where winter snow cover occurs more frequently (WRDS 1997), reestablishment of Wyoming big sagebrush is more successful (Lyford 1995). Winter snow cover may reduce wind exposure and desiccation, thereby enhancing seedling survival (Burke et al. 1989, Young et al. 1990). In northeast Wyoming, winter snow cover is sporadic to nonexistent. Wyoming big sagebrush is difficult to reestablish on northeast Wyoming mined-lands (Coenenberg 1982, Cockrell et al. 1995, Stahl et al. 1998). These regional differences in reestablishment success appear to be due to differences in the amount of winter precipitation. Our results indicate that only years with above-average winter precipitation after the first growing season are conducive to high levels of Wyoming big sagebrush recruitment.

Climatic conditions supporting widespread pulses of big sagebrush establishment on native sites should be examined in greater depth. Since factors affecting plant establishment are extremely complex, we cannot conclude that winter precipitation is the primary determinant of cohort establishment. We did not examine the effects of snow cover on Wyoming big sagebrush recruitment. Since similar combinations of monthly precipitation and mean monthly temperature exist at all geographic scales for each subspecies, our data provide strong evidence that precipitation variables significantly affect high levels of seedling recruitment on native, undisturbed big sagebrush sites throughout Wyoming.

\section{Literature Cited}

Bai, Y., T. Booth, and E.R. Roos. 1997. Effect of seed moisture on Wyoming big sagebrush seed quality. J. Range Manage. 50:419-422.

Beetle, A. A. and K. L. Johnson. 1982. Sagebrush in Wyoming. University of Wyo. Agr. Exp. Sta., Laramie, Wyo.

Bonham, C.D., T.R. Cottrell, and J.F. Mitchell. 1991. Inferences for life history strategies of Artemisia tridentata subspecies. J. of Veg. Sci. 2:339-344.

Brooks, K.N., P.F. Ffolliott, H.M. Gregersen, and J.L. Thames. 1991. Hydrology and the Management of Watersheds. Iowa State University Press, Ames, I.a. 
Burke, I.C., W.A. Reiners, and R.K. Olson. 1989. Topographic control of vegetation in a mountain big sagebrush steppe. Vegetatio. 84:77-86.

Cawker, K.B. 1980. Evidence of climatic control from population age structure of Artemisia tridentata Nutt. in southern British Columbia. J. Biogeogr. 7:237-248.

Christensen, R. 1997. Log-Linear Models and Logistic Regression. Springer, New York, N.Y.

Cochran, W.G. 1977. Sampling Techniques. John Wiley \& Sons, Inc., New York, N.Y.

Cockrell, J.R., G.E. Schuman, and D.T. Booth. 1995. Evaluation of cultural methods for establishing Wyoming big sagebrush on mined lands p. 784-795. In: G.E Schuman and G.F. Vance (ed.) Decades later: A time for reassessment. Amer. Soc. Surf. Mining Reclam., Princeton, W.V.

Coenenberg, J.G. 1982. Methods for establishment of diverse native plant communities at the Rosebud Mine. p.B6(1-20). In: Proc. Symp. Mining Reclam. of Coal Mined Lands in the Northern Great Plains. Mont. Agr. Exp. Sta. Bozeman, Mont.

Diettert, R.A. 1938. The morphology of Artemisia tridentata Nutt. Lloydata, 1:3-74.

Eissenstat, D.M. and M.M. Caldwell. 1988. Competitive ability is linked to rates of water extraction. Oecologia 75:1-7.

Ferguson, C. W. 1964. Annual rings in big sagebrush. Papers of the Laboratory of TreeRing Research No. 1. The Univ. of Arizona Press, Tucson, Ariz.
Harniss, R.O. and W.T. McDonough. 1976. Yearly variation in germination in three subspecies of big sagebrush. J. Range Manage. 29:167-168.

Hosmer, D.W. and S. Lemeshow. 1989. Applied Logistic Regression. Wiley \& Sons, New York, N.Y.

Jones, G.P. 1991. Seedling survival and adult plant water relations of black sagebrush and big sagebrush in the Laramie Basin. Ph.D. Thesis, Univ. of Wyoming. Laramie, Wyo.

Lyford, M.E. 1995. Shrub establishment on drastically disturbed lands. M.S. Thesis, Univ. Wyoming. Laramie, Wyo.

May, M. 1975. Moisture relationships and treatments in revegetating strip mines in the arid west. J. Range Manage. 28:334-335.

McDonough, W.T. and R.O. Harniss. 1974. Effects of temperature on germination in three subspecies of big sagebrush. J. Range Manage. 27:204-205.

Moss, E.H. 1940. Interxylary cork in Artemisia with reference to its taxonomic significance. Amer. J. Bot., 27:762-768.

Perryman, B.L. and R.A. Olson. 2000. Agestem diameter relationships of big sagebrush and their management implications. J. Range. Manage. 53:342-346.

Schuman, G.E., D.T. Booth, and J.R. Cockrell. 1998. Cultural methods for establishing Wyoming big sagebrush on mined lands. J. Range Manage. 51:223-230.

Stahl, P. D., G.E. Schuman, S.M. Frost. and S.E. Williams. 1998. Arbuscular mycorrhizae and water stress tolerance of Wyoming big sagebrush seedlings. J. Soil Sci. 62:1309-1313.
Sturges, D.L. 1976. Hydrologic relations on undisturbed and converted big sagebrush lands: The status of our knowledge. Forest Service Res. Pap. RM-140. Fort Collins, Colo.

Vale, T.R. 1974. Sagebrush conversion projects: An element of contemporary environmental change in the western United States. Biol. Cons. 6:274-284.

Went, R.W. 1955. The ecology of desert plants. Sci. Amer. 192:68-75.

West, N.E. 1978. Basic synecological relationships of sagebrush dominated lands in the Great Basin and Colorado plateau. In: The sagebrush ecosystem, A symposium, Logan, Ut., College of Natural Resources, Utah State Univ., Logan, Ut.

West, N.E., K.H. Rea, and R.O. Harniss. 1979. Plant demographic studies in sagebrush-grass communities of southeastern Idaho. Ecol. 60:376-388.

WRDS (Wyoming Water Resources Data System). 1997. National Weather Service Climate Station Data. Wyoming Water Resources Center, University of Wyoming, Laramie, Wyo.

Young, J.A., R.A. Evans, and D.E. Palmquist. 1990. Soil surface characteristics and emergence of big sagebrush seedlings. J. Range Manage. 43:358-367.

Young, J.A., D.E. Palmquist, and R.A. Evans. 1991. Temperature profiles for germination of big sagebrush seeds from native stands. J.Range Manage. 44:385-390. 